\title{
PERTAMBAHAN BOBOT BADAN DAN ANALISIS KELAYAKAN USAHA PENGGEMUKAN KAMBING YANG DISUPLEMENTASI PROBIOTIK BIOPLUS DI KELOMPOKTANI SRI REJEKI KECAMATAN PAYUNG SEKAKI KOTA PEKANBARU
}

\author{
Body Weight Gain and Feasibility Study of Feedlot Goat Supplemented with \\ Bioplus Probiotic in Sri Rejeki Farmers Payung Sekaki Subdistrict \\ Pekanbaru City
}

\author{
Muhammad Ilham*, Rizal Krisna, Sudradjat \\ Program Studi Penyuluhan Peternakan dan Kesejahteraan Hewan \\ Jurusan Peternakan, Politeknik Pembangunan Pertanian Bogor \\ *Korespondensi penulis: muhammadilham251197@gmail.com
}

\begin{abstract}
Regarding of Statistic Pekanbaru in 2019, the goat population in Payung Sekaki Subdistrict are 329 heads. The goat population can be improved by feed manipulation technique to increase goat productivity. One of feed manipulation technique is probiotic supplementation. The study aims to analyze body weight gain and feasibility of goat fattening analysis supplemented Bioplus probiotic. The study was designed in Randomized Block Design with 3 treatments and 4 replications. The treatments such us $P 0=$ control (field grass), $P 1=$ control + Bioplus $100 \mathrm{~g}, P 2=$ control + Bioplus $150 \mathrm{~g}$. The variables measured was average daily gain (ADG) and business analysis such us income, Break Even Point (BEP) production, BEP price, Revenue Cost Ratio ( $R / C$ ratio) and Benefit Cost Ratio (B/C ratio). ADG data was analysis by Anova and Least Significant Difference. The result showed that the supplementation Bioplus probiotics increase daily gain of goat with the average of daily gain respectively P0 53,13 g/head/day, P1 95,63 g/head/day dan P2 127,50 $\mathrm{g} / \mathrm{head} / \mathrm{day}$. The result of feasibility analysis showed that $P 2$ has the highest income Rp840.800,$R / C$ ratio $1.140(>1)$ and $P 0$ with income $R p 15.000$,- with $R / C$ ratio . Supplementation of Bioplus probiotic with dose $150 \mathrm{~g} / \mathrm{head} /$ day increased average daily gain and increased income to provide better business feasibility of fattening goat.
\end{abstract}

Keywords: Bioplus, feasibility, goat, probiotic

\begin{abstract}
ABSTRAK
Berdasarkan Statistik Pekanbaru tahun 2019 populasi kambing di Kecamatan Payung Sekaki adalah 329 ekor. Populasi tersebut masih dapat diperbaiki dengan teknik manipulasi pakan agar produktivitas kambing meningkat. Teknik manipulasi pakan yang dapat direkomendasikan adalah probiotik Bioplus. Penelitian bertujuan menganalisis pertambahan bobot badan dan analisis usaha penggemukan kambing yang disuplementasi probiotik Bioplus. Penelitian dirancang dengan Rancangan Acak Lengkap (RAL) dengan 3 perlakuan dan 4 ulangan. Perlakuan yang diberikan diantaranya: $\mathrm{P} 0=$ kontrol (rumput lapang), $\mathrm{P} 1=$ kontrol + Bioplus $100 \mathrm{~g}$ dan $\mathrm{P} 2=$ kontrol + Bioplus $150 \mathrm{~g}$. Peubah yang diukur diantaranya pertambahan bobot badan harian (PBBH) dan peubah analisis usaha seperti pendapatan, Break Even Point (BEP) produksi, BEP harga, Revenue Cost Ratio (R/C ratio) dan Benefit Cost Ratio (B/C ratio). Data PBBH dianalisis dengan Analisis Anova dan uji lanjut Beda Nyata Terkecil (BNT) sedangkan data kelayakan usaha dianalisis secara deskriptif. Hasil penelitian menunjukkan pemberian probiotik Bioplus memberikan pengaruh yang nyata terhadap $\mathrm{PBBH}$ kambing $(\mathrm{P}<0,05)$ dengan $\mathrm{PBBH}$ masingmasing perlakuan P0 53,13 g/ekor/hari, P1 95,63 g/ekor/hari dan P2 127,50 g/ekor/hari. Hasil analisis kelayakan usaha beternak kambing dengan pemberian probiotik Bioplus menunjukanP2 memiliki tingkat pendapatan tertinggi yaitu sebesar Rp840.800 dan sudah dapat dikatakan memiliki keuntungan karena ( $\mathrm{R} / \mathrm{C}$ ratio) menunjukan angka $>1$ yaitu sebesar 1,140 dan P0
\end{abstract}


memiliki pendapatan terendah yaitu sebesar Rp15.200 dengan $R / C$ ratio sebesar 1,002. Pemberian probiotik Bioplus dosis 150 g/ekor mampu meningkatkan PBBH dan peningkatan pendapatan dan memberikan kelayakan usaha yang lebih baik.

Kata kunci: bioplus, kambing, kelayakan usaha, probiotik

\section{PENDAHULUAN}

Jumlah ternak kambing di Indonesia saat ini menurut catatan sekitar 18,97 juta (data tahun 2019) yang sebagian besar $(58,28 \%)$ tersebar di Pulau Jawa (Ditjen PKH 2019). Berdasarkan data Badan Pusat Statistik, pada tahun 2019 jumlah kambing yang terdapat di Kecamatan Payung Sekaki adalah 329 ekor (Badan Pusat Statistik Kota Pekanbaru 2019). jumlah tersebut seharusnya dapat dimaksimalkan dengan cara diterapkannya teknik manipulasi pakan agar produktivitas ternak kambing tetap tinggi.

Teknik manipulasi pakan pakan yang sedang marak dikembangkan adalah suplementasi probiotik. Pemberian probiotik merupakan salah satu faktor penting dalam peningkatan produktivitas ternak. Perbaikan produktivitas ternak yang memperoleh pakan hijauan berkualitas rendah dapat dapat dilakukan dengan mengoptimalkan efisiensi fermentasi rumen.

Probiotik adalah bahan aditif yang mengandung mikroorganisme hidup sehingga dapat membantu proses pencernaan pakan dalam tubuh ternak.
Probiotik yang baik mengandung mikroba yang bersifat tidak pathogen, aktif di dalam rumen (tidak dorman) dan dapat hidup di saluran pencernaan secara anaerob (Nur 2017). Mekanisme kerja probiotik dengan cara memperbaiki keseimbangan microflora dalam usus dan meningkatkan jumlah mikroba yang menguntungkan sehingga dapat menghambat perkembangbiakan bakteri pathogen (Lutfiana et al. 2015). Probiotik menghasilkan efek yang bermanfaat bagi ternak dengan cara meningkatkan penyerapan nutrisi yang menyebabkan performa pertumbuhan yang lebih tinggi, meningkatkan selulolitas populasi bakteri rumen dan meningkatkan asupan pakan, performa pertumbuhan, konversi pakan dan penyerapan nutrisi (Saleem et al. 2017).

Bioplus merupakan produk campuran mikroorganisme yang telah berbentuk serbuk kering dan teknologi produksinya dikembangkan di Balai Penelitian Ternak (Balitnak) Ciawi. Bioplus diambil dari isi perut ternak potong dan dicampur dengan inoculum yang sudah diadaptasi dengan suatu substrat tertentu. Bila substrat yang ditambahkan adalah jerami, maka 
Bioplus tersebut disebut Bioplus serat karena dapat diasumsikan dapat memecah serat lebih baik. Bila substrat yang ditambahkan adalah daun kaliandra, maka Bioplus tersebut disebut Bioplus racun karena diasumsikan dapat memecah tannin (racun) dalam kaliandra (Winugroho dan Widiawati 2006). Penggunaan Bioplus pada kambing dengan dosis $200 \mathrm{gr}$ menghasilkan nilai kecernaan bahan kering (BK) sebesar 72,07\%, kecernaan bahan organik (BO) $75,24 \%$ dan kecernaan protein kasar (PK) sebesar 61,85\% (Nesya 2014). Tujuan penelitian ini adalah untuk mengevaluasi penggunaan Bioplus dalam ransum terhadap pertambahan bobot badan dan analisis kelayakan usaha penggemukan ternak kambing di kelompoktani Sri Rezeki.

\section{METODE}

\section{Alat dan Bahan}

Sebanyak 12 ekor kambing jantan digunakan sebagai unit percobaan dengan umur 8-12 bulan. Setiap kambing ditempatkan dalam kandang individu yang dilengkapi dengan tempat pakan. Ransum yang diberikan berupa rumput lapang dan pemberian probiotik Bioplus. Alat dan bahan yang digunakan diantaranya peralatan kandang, baskom, timbangan gantung dan timbangan digital.
Penelitian dilaksanakan selama 40 hari terdiri atas 10 hari adaptasi pakan dan 30 hari pengambilan data. Satu minggu sebelum pelaksanaan penelitian, ternak diberikan obat cacing dan multivitamin untuk menyamakan kondisi kesehatan kambing unit percobaan. Pemberian probiotik pada awal penelitian atau pada hari ke-0 perlakuan dan hanya diberikan satu kali. Pemberian probiotik dilakukan dengan cara dicekokkan pada ternak kambing. Pada hari selanjutnya kambing diberikan makan setiap hari dan dilakukan penimbangan bobot badan agar didapatkan nilai pertambahan bobot badan harian (PBBH).

\section{Pengukuran Peubah PBBH}

Data bobot badan diperoleh dengan cara penimbangan kambing selama percobaan berlangsung. Penimbangan dilakukan pada hari ke-0, 15 dan 30. PBBH (g/ekor/hari) dihitung menggunakan rumus menurut Supratman et al. (2016) sebagai berikut:

$$
\text { PBBH }=\frac{\text { Bobot akhir }- \text { Bobot awal }}{\text { Lama hari penimbangan }}
$$

\section{Kelayakan Usaha}

Analisis kelayakan usaha penggemukan kambing dilakukan selama 40 hari sebanyak 12 ekor. Peubah yang dihitung diantaranya nilai Benefit Cost Ratio (B/C ratio), Revenue

\section{Prosedur}


Cost Ratio (R/C ratio), Break Even Point

(BEP) harga dan BEP produksi.

\section{Rancangan dan Analisis Data}

Penelitian menggunakan

Rancangan Acak Lengkap dengan tiga perlakuan dan 4 ulangan. Perlakuan terdiri atas $\mathrm{PO}=$ kontrol (rumput lapang), $\mathrm{P} 1=$ kontrol + Bioplus $100 \mathrm{~g}$ dan P2 = kontrol + Bioplus $150 \mathrm{~g}$. Peubah yang diukur dalam penelitian diantaranya pendapatan, BEP harga, BEP produksi, $\mathrm{B} / \mathrm{C}$ ratio dan $\mathrm{R} / \mathrm{C}$ ratio. Data $\mathrm{PBBH}$ dianalisis dengan Analysis of variance (Anova) dan uji lanjut Beda Nyata
Terkecil (BNT) sedangkan data kelayakan usaha dianalisis secara deskriptif.

\section{HASIL DAN PEMBAHASAN}

\section{Pengaruh Pemberian Probiotik Bioplus terhadap PBBH}

Berdasarkan hasil pengukuran bobot badan, terjadi peningkatan yang bobot badan kambing dengan rata-rata peningkatan bobot badan P0 sebesar 2,1 kg, P1 sebesar 3,8 kg, P2 sebesar $5,1 \mathrm{~kg}$. Data pertambahan bobot badan harian kambing dapat dilihat pada Tabel 1.

Tabel 1 PBBH ternak kambing yang disuplementasi Bioplus

\begin{tabular}{cc}
\hline Perlakuan & PBBH (g/ekor/hari) \\
\hline P0 & 53,13 \\
P1 & 95,63 \\
Peterangan: $\mathrm{P} 0=$ kontrol, P1 = kontrol + Bioplus 100 gr/ekor/hari dan $\mathrm{P} 3,50$ \\
g/ekor/hari. Superscript berbeda pada kolom yang sama menunjukkan perbedaan \\
nyata $(\mathrm{P}<0,05)$
\end{tabular}

Hasil penelitian menunjukkan terjadi kenaikan $\mathrm{PBBH}$ yang signifikan dari pemberian probiotik Bioplus pada ternak kambing $(P<0,05)$. Pemberian dosis sebesar $150 \mathrm{~g} / \mathrm{ekor} / \mathrm{hari}$ mampu memberikan $\mathrm{PBBH}$ terbaik dibanding perlakuan lainnya $(P<0,05)$. Nilai $\mathrm{PBBH}$ ternak kambing yang disuplementasi probiotik Bioplus pada perlakuan P0, p1 dan P2 berturut-turut 53,13 g/ekor/hari, 95,63 g/ekor/hari dan 127,50 g/ekor/hari. Peningkatan bobot badan kambing sebagai akibat dari meningkatnya keseimbangan mikroba hidup yang menguntungkan dalam saluran pencernaan kambing sehingga dapat meningkatkan efisiensi penggunaan dan daya cerna pakan berkualitas rendah (Riswandi et al. 2015).

Peningkatan efisiensi pencernaan ini terjadi dikarenakan adanya penambahan mikroorganisme di saluran pencernaan kambing sebagai akibat dari pemberian probiotik Bioplus, mikroorganisme tersebut yaitu 
kelompok bakteri Bacteroides succinogenes;

Ruminococcus

flavefaciens; Bacteroides

clostridiformis Megasphaera elsdenil; kelompok fungi Neocalimastic frontalis; Ruminomyces sp; anaeromyces; dan Orpinomyces sp Balitbangtan (2018). Penambahan mikroorganisme ini akan akan membantu pencernaan kambing dalam memecah serat dan tannin lebih naik dikarenakan Bioplus yang dipakai merupakan Bioplus pedet yang memakai jerami dan daun kaliandra sebagaisubstratnya. Selain membantu fermentasi pada rumen dengan memproduksi enzim selulase, mikroorganisme ini akan dicerna sebagai sumber protein di abomasum sehingga dapat memperbaiki kualitas pakan yang diberikan. Bioplus merupakan probiotik dengan target organ rumen yang memiliki manfaat dalam meningkatkan populasi mikroba rumen melalui suplementasi sehingga aktivitas fermentasi rumen dapat berjalan optimal dan meningkatkan kecernaan nutrien (Winugroho dan
Widiawati 2006).

Balitbangtan (2018) menyatakan bahwa Bioplus dapat meningkatkan efisiensi penggunaan dan daya cerna pakan kualitas rendah, kesehatan ternak, memacu pertumbuhan ternak, mencegah penurunan bobot badan pada musim kemarau dimana kualitas pakan menjadi sangat jelek dan tidak segar, meningkatkan bobot tubuhinduk dan nisbah konsumsi pakan.

\section{Analisis Usaha}

Hasil analisis usaha pemeliharaan kambing dengan hanya diberikan hijauan (P0) menghasilkan pendapatan sebesar Rp15.200,-/40 hari atau Rp380,-/hari. Sedangkan pemeliharaan kambing dengan diberikan hijauan dan $100 \mathrm{~g}$ Bioplus (P1) menghasilkan pendapatan sebesar Rp480.400/40 hari atau Rp12.010,-/hari. Pemeliharaan kambing dengan diberikan hijauan dan $150 \mathrm{~g}$ Bioplus menghasilkan pendapatan sebesar Rp840.800,- atau Rp21.020,-/hari. Selengkapnya dapat dilihat pada Tabel 2. 
Tabel 2. Analisis kelayakan usaha penggemukan kambing

\begin{tabular}{lccc}
\hline Peubah & P0 & P1 & P2 \\
\hline Pendapatan (Rp) & 15.200 & 480.000 & 840.800 \\
BEP Produksi (kg) & 19,823 & 19,269 & 19,460 \\
BEP Harga (Rp) & 74.807 & 69.398 & 65.746 \\
R/C Ratio & 1,002 & 1,080 & 1,140 \\
B/C Ratio & 0,002 & 0,080 & 0,140 \\
\hline
\end{tabular}

Keterangan: P0 = kontrol, P1 = kontrol + Bioplus 100 gr/ekor/hari dan P3 = Kontrol + Bioplus $150 \mathrm{~g} / \mathrm{ekor} / \mathrm{hari}$.

BEP Produksi P0 yaitu 19,823 kg yang artinya titik impas akan tercapai bila pada saat dijual beratkambing $\mathrm{PO}$ sebesar 19,823 kg. Pada P0 titik impas tidak tercapai dikarenakan pada saat dijual, rata-rata berat kambing $\mathrm{P} 0$ yaitu 19,404 kg; BEP Produksi P1 yaitu $19,269 \mathrm{~kg}$ yang artinya titik impas akan tercapai bila pada saat dijual berat kambing P0 sebesar 19,269 kg. Pada P0 titik impas tidak tercapai dikarenakan padasaat dijual, rata-rata berat kambing P1 yaitu 21,104 kg; BEP Produksi P2 yaitu $19,460 \mathrm{~kg}$ yang artinya titik impas akan tercapai bila pada saat dijual berat kambingP0 sebesar 19,460 kg. Pada P0 titik impas tidak tercapai dikarenakan pada saat dijual, rata-rata berat kambing P2 yaitu 22,38 kg. BEP Harga P0 yaitu Rp74.807 yang artinya titik impas tercapai bila harga jual Rp74.807/kg; BEP Harga P1 Rp69.398 yang artinya titik impas tercapai bila harga jual Rp69.398/kg; BEP Harga P2 Rp65.746 yang artinya titik impas tercapai bila harga jual Rp65.746.
Ketiga perlakuan ini telah mencapai titik impas dikarenakan harga jual ketiga perlakuan sebesar P2 Rp75.000. R/C Ratio yang didapat untuk P0 sebesar 1,002 yang artinyaP0 dapat dikatakan untung dikarenakan nilai R/C Ratio $>1$; R/C Ratio yang didapat untuk P1 sebesar 1,080 yang artinya P1 dikatakan untung dikarenakan nilaiR/C Ratio $>1$; R/C Ratio yang didapat untuk P2 sebesar1,140 yang artinya P2 dapat dikatakan untung dikarenakan nilai $\mathrm{R} / \mathrm{C}$ Ratio $>1$. B/C Ratio P0 sebesar 0,002 yang artinya setiap pengeluaran Rp1.000 akan menghasilkan keuntungan Rp2; B/C Ratio P1 sebesar 0,080 yang artinya setiap pengeluaran Rp1.000 menghasilkan keuntungan Rp80; B/C Ratio P2 sebesar 0,140 yang artinya setiap pengeluaran Rp1.000 menghasilkan keuntungan Rp140. Secara garis besar, ketiga perlakuan ini dapat dikatakan tidak layakdikarenakan nilai $\mathrm{B} / \mathrm{C}$ Ratio < 1. Hal ini menunjukkan pada perlakuan P1 dan P2 usaha penggemukan kambing memiliki 
pendapatan yang lebih tinggi dibanding kontrol dan menjadi lebih layak dijalankan.

\section{SIMPULAN DAN SARAN}

Suplementasi probiotik Bioplus
dengan dosis 150 g/ekor mampu meningkat pertambahan bobot badan harian ternak kambing dengan ransum basal berupa rumput lapang serta terjadi peningkatan pendapatan peternak dan usahanya menjadi layak untuk dijalankan. Diperlukan diseminasi hasil penelitian terutama pada Penyuluh Pertanian di Kecamatan Paung Sekaki dan peternak kambing untuk menerapkan suplementasi probiotik Bioplus dalam ransum kambing untuk meningkatkan produksi.

\section{DAFTAR PUSTAKA}

Badan Pusat Statistik Kota Pekanbaru. 2019. Kecamatan Payung Sekaki dalam Angka 2019. Pekanbaru: CV MN Grafika.

[Balitbangtan] Badan Penelitian dan Pengembangan Pertanian. 2018. 600 Teknologi Inovatif Pertanian. Mulyandari RSH, editor. Jakarta: IAARD Press.

[Ditjen $\mathrm{PKH}$ ] Direktorat Jendral Peternakan dan Kesehatan Hewan. 2019. Statistik Peternakan dan Kesehatan Hewan 2019. Jakarta:
Kementerian Pertanian.

Lutfiana K, Kurtini T, Hartono M. 2015. Pengaruh pemberian probiotik dari mikroba lokal terhadap gambaran darah ayam petelur. Jurnal IImiah Peternakan Terpadu. Vol 3 (3): 151-156.

Nesya OC. 2014. Pengaruh Supplementasi Probiotik Bioplus pada Ransum Berbasis Limbah Kelapa Sawit terhadap Kecernaan in vitro Bahan Kering (BK), Bahan Organik (BO), dan Protein Kasar (PK). [Skripsi]. Padang: Universitas Andalas.

Nur F. 2017. Potensi Bakteri Asam Laktat yang Diisolasi dari Dangke sebagai Kandidat Probiotik dalam Menghambat Bakteri Patogen [Disertasi]. Makassar: Universitas Hasanuddin.

Riswandi, Muhakka, Lehan M. 2015. Evaluasi Nilai Kecernaan secara in vitro Ransum Ternak Sapi Bali yang Disuplementasi dengan Probiotik Bioplus. Jurnal Peternakan Sriwijaya. Vol 4 (1): 35-46.

Saleem AM, Zanouny AI, Singer AM. 2017. Growth Performance, Nutrient Digestibility and blood metabolites of lambs fed diets supplemented with probiotics 
during pre- and post-weaning

period. Asian-Australian Journal

of Animal Science. Vol 30 (4):

523-530.

Supratman $H$, Setiyatwan $H$,

Budinuryanto DC, Fitriani A,

Ramdani D. 2016. Pengaruh

Imbangan Hijauan dan

Konsentrat Pakan Komplit

terhadap Konsumsi,

Pertambahan Bobot Badan dan

Konversi Pakan Domba. Jurnal

IImu Ternak. Vol 16 (1): 31-35.

Winugroho M, Widiawati Y. 2006. The Utilization of Probiotics Bioplus, Saccharomyces and Candida Utilis to Improve Dairy Cattle Productivity. Animal Production and Sustainable Agriculture in the Tropics. The $4^{\text {th }}$ International Seminar on Tropical Animal Production; 2018 Nov 8-9; Yogyakarta: Faculty of Animal Science, Gadjah Mada University. HIm 479-483. 